\title{
Influencia del número de llaves en la resistencia a cortante de juntas secas postensadas
}

\section{Influence of the number of keys on the shear strength of post-tensioned dry joints}

\author{
M. Alcalde(*), H. Cifuentes(*), F. Medina(*)
}

\section{RESUMEN}

La resistencia a cortante en las juntas secas es una parte importante del diseño de estructuras de dovelas postensadas. Sin embargo, la formulación de las distintas normativas no se ajusta al comportamiento de las juntas con llaves múltiples. En este trabajo se analiza el comportamiento en fractura de las juntas secas con llaves bajo solicitaciones de cortante, centrándose en la influencia del número de llaves en la resistencia de la junta y la tensión tangencial media. Para ello, se modeliza en elementos finitos cuatro tipos de junta, de una a siete llaves. Los resultados muestran que la tensión tangencial media transferida por la junta disminuye al aumentar el número de llaves, siendo este efecto menor conforme aumenta la tensión de compresión actuante en la junta. En este trabajo se presenta una fórmula de ajuste de los resultados numéricos obtenidos incluyendo un factor que considera la dependencia del número de llaves.

Palabras clave: juntas secas; llaves múltiples; estructuras de dovelas; hormigón pretensado; resistencia a cortante.

\section{SUMMARY}

The shear strength of dry joints plays an important role in the design of prestressed segmental structures. However, the formulations of different design codes do not conform to the behavior of multiple-keyed joints. This paper analyzes the fracture behavior of dry keyed joints under shear loading, focusing on the influence of the number of keys on the joint capacity and its average shear stress. It has been developed a finite element model of four different types of joints, with a number of keys varying between one and seven. The results show that the average shear stress transferred across the joint decreases with the number of keys but this effect is less appreciated as the prestressing stress increases. In this paper it is presented a formula of adjustment of the obtained numerical results including a factor with the dependence on the number of keys.

Keywords: dry joints; multiple-keyed joint; segmental structures; prestressed concrete; shear capacity

(*) Universidad de Sevilla (Sevilla, España). 


\section{INTRODUCCIÓN}

El uso de juntas secas con llaves es muy común en la construcción de puentes de dovelas postensadas, debido a la rapidez que permite en su construcción y a que no depende de las condiciones climatológicas, como ocurre si se aplica resina epoxi en la unión $(1,2)$.

Sin embargo, la diversa formulación existente para el cálculo de la resistencia a cortante de las juntas secas con llaves de las distintas normativas y autores presenta valores muy dispares. Esto ha dado lugar a estudios experimentales realizados por distintos autores para analizar el comportamiento de las juntas con llaves (2-6), así como a diversos modelos numéricos (6-11). La configuración tanto de los ensayos como de los modelos numéricos recogidos en la bibliografía es muy diferente. Este hecho dificulta la comparación entre los resultados disponibles, siendo necesario un estudio pormenorizado para cada caso concreto.

Con respecto a la normativa española, se tiene la fórmula propuesta por las recomendaciones de la Asociación Técnica Española del Pretensado (12). Dicha fórmula depende del área total de la junta, sin distinguir la resistencia aportada por las llaves [1]:

\section{INTRODUCTION}

The use of multiple-keyed dry joints is very popular in prestressed segmental bridge construction due to speed of erection and independence of weather conditions, in contrast to epoxied joints $(1,2)$.

However, the existing formulas to estimate the shear capacity of keyed dry joints from different design codes and authors lead to very differing values. So several experimental studies have been carried out to analyze the behavior of keyed joints (2-6) as well as various numerical models have been developed (6-11). Nevertheless, the configurations of both experimental studies and numerical models found in the literature are very different. This fact makes it difficult to compare the current available results between them because it would be necessary a detailed study for each case.

Regarding the Spanish design code, there is a formula recommended by ATEP (12). This formula depends on the total area of the joint surface, without distinguishing the strength contribution of the keys [1]:

$$
V_{u}=A_{j}\left(1.14 \sigma_{n}+0.0564 \sqrt{f_{c d}}\right)
$$

Siendo:

$V_{u}=$ Resistencia última a cortante de las juntas secas con llaves $(\mathrm{N})$.

$A_{j}=$ Área del plano de la junta $\left(\mathrm{mm}^{2}\right)$.

$f_{c d}=$ Resistencia de cálculo a compresión del hormigón (MPa).

$\sigma_{n}=$ Tensión de compresión en la junta (MPa).

Por otro lado, en la normativa americana, la formulación propuesta por la AASHTO (13) establece que la resistencia a cortante de las juntas secas con llaves se calcula como la resistencia del área con llaves más la resistencia de la parte plana de la junta [2]:

$$
V_{n}=A_{k} \sqrt{f_{c k}}\left(0.2048 \sigma_{n}+0.9961\right)+0.6 A_{s m} \sigma_{n}
$$

Siendo:

$V_{n}=$ Resistencia nominal a cortante de las juntas secas con llaves $(\mathrm{N})$.

$A_{k}=$ Área de la base de las llaves en el plano de la junta $\left(\mathrm{mm}^{2}\right)$.

$A_{s m}=$ Área de contacto sin llaves en el plano de la junta $\left(\mathrm{mm}^{2}\right)$.

$f_{c k}=$ Resistencia característica a compresión del hormigón (MPa) $\left(f_{c}^{\prime}\right.$ en (13)).

Where: $\left(m m^{2}\right)$. joint plane $\left(\mathrm{mm}^{2}\right)$. ( $f_{c}^{\prime}$ in (13)).
Where:

$V_{u}=$ Ultimate shear capacity of keyed dry joint $(N)$

$A_{j}=$ Total area of the joint surface $\left(\mathrm{mm}^{2}\right)$.

$f_{c d}=$ Design value of concrete compressive strength (MPa).

$\sigma_{n}=$ Compressive stress in the joint (MPa).

In the American design codes, the formula proposed by AASHTO (13) separates the shear strength that is transmitted by the keys from the strength provided by the smooth surfaces in contact [2]:

$V_{n}=$ Nominal shear capacity of keyed dry joint $(N)$.

$A_{k}=$ Area of the base of all keys in the joint plane

$A_{s m}=$ Area of contact between smooth surfaces in the

$f_{c k}=$ Characteristic concrete compressive strength (MPa) 
Turmo 2006 (1) realizó un estudio pormenorizado de la diversa formulación propuesta por distintos autores, así como de los resultados experimentales disponibles en la bibliografía, comparando dichos resultados con la resistencia calculada por las diversas fórmulas, incluida la fórmula de las recomendaciones españolas (12) y de la normativa americana (13). Así, propuso la siguiente fórmula [3] para el eurocódigo, basada en la fórmula de la AASHTO que es la que mejor se ajusta a los resultados (1):
Turmo 2006 (1) reviewed the varying formulation used to evaluate the joint shear capacity as well as the experimental data published in the literature. He compares this data with the shear capacity obtained from different formulas, including the ATEP (12) and the AASHTO formulas (13). Then, Turmo proposed the following formula [3] to be included in the Eurocode, based on the AASHTO formula that showed the best agreement with the experimental results (1):

$$
V_{n}=A_{k} \underset{100}{\sqrt[3]{f_{c k}^{2}}}\left(7 \sigma_{n}+33\right)+0.6 A_{s i n} \sigma_{n} \quad \text { si } \quad f_{c k} \leq 50 \mathrm{MPa}
$$

Rombach (14) hizo un análisis del comportamiento de juntas con llaves múltiples mediante un modelo de elementos finitos constatado experimentalmente, y propuso la siguiente fórmula [4]:
Rombach (14) analyzed the behavior of multiple-keyed joints by a finite element model experimentally verified and he proposed the following formula [4]:

$$
V_{n}=0.14 A_{k} f_{c k}+0.65 A_{j} \sigma_{n}
$$

Zhou (3) realizó una serie de ensayos experimentales analizando el comportamiento de las juntas secas con una llave y con tres llaves. Comparando estos resultados con la formulación propuesta por la AASHTO, se observa una sobrestimación de la capacidad a cortante de las juntas secas con llaves múltiples, sobre todo para pequeños valores de la tensión de pretensado. Esto es debido a que las fórmulas propuestas provienen de una extrapolación de estudios realizados con una sola llave, y por tanto no tienen en cuenta que en el caso de llaves múltiples no todas las llaves llegan a desarrollar completamente su resistencia debido a su rotura secuencial. Así, Zhou propuso la introducción de coeficientes correctores en la formulación de la AASHTO para el caso de juntas secas con múltiples llaves conjugadas (3).

Por todo ello, en este trabajo se desarrolla un modelo numérico que permite predecir la resistencia a cortante de las juntas. Se realiza un modelo de junta en elementos finitos, con un número variable de llaves, para distintas presiones de pretensado, en el que mediante un modelo cohesivo para el hormigón se visualiza la formación y crecimiento de grietas, hasta la pérdida total de resistencia de las juntas. Se presenta una fórmula de ajuste de los resultados obtenidos, que incluye un factor hasta ahora no utilizado, dependiente del número de llaves, que hace que la resistencia disminuya con el número de llaves, coherente con los resultados experimentales obtenidos por Zhou.
Zhou (3) performed a series of experimental tests and analyzed the behavior of dry single-keyed joints and threekeyed joints. Comparing the results with the AASHTO formula, it can be seen that the shear capacity of the multiple-keyed dry joints is overestimated, especially at low confinement conditions. This is due to the fact that the formula proposed by AASHTO was derived from experimental results of single-keyed joints. This formula does not take into account that in multiple-keyed joints not all the keys fully develop their capacity due to sequential failure. Zhou proposed introducing a reduction factor in the AASHTO formula when the number of keys was greater than one (3).

In this work, it has been developed a finite element model to estimate the shear capacity of the joints. The joint has been modeled with a number of keys varying between one and seven, applying different prestressing stresses. The cohesive model used for concrete allows to visualize the crack formation and propagation until the complete loss of strength of the joint. In this paper it is presented a regression equation of the results that includes a factor not used before. This factor depends on the number of keys and makes the strength decrease with the number of keys, which is consistent with the experimental results obtained by Zhou. 


\section{MODELO NUMÉRICO}

\subsection{Validación del modelo}

El modelo de material utilizado se basa en el modelo de banda fisurada (15), con una ley de ablandamiento en tracción del hormigón fisurado en la dirección perpendicular a la grieta. El módulo de elasticidad transversal del material fisurado va disminuyendo conforme aumenta la apertura de grieta, a través del modelo de retención de cortante. La fórmula matemática utilizada para este modelo es la ley potencial propuesta por Rots y Blaauwerdraad (16).

El modelo permite definir un desplazamiento crítico, de manera que cuando la fisuración local del elemento alcanza ese valor, se considera que se produce el fallo del elemento y es eliminado de la malla. Este valor de fallo corresponde a una apertura de grieta a la que las tensiones han alcanzado un valor nulo. Esto permite visualizar la trayectoria de las grietas.

Para la validación del modelo de material, se realiza un análisis numérico correspondiente a un ensayo a flexión en tres puntos sobre una probeta entallada, comparando los resultados con los obtenidos experimentalmente (17). El modelo se realiza con el programa Abaqus/Explicit. Los elementos utilizados son CPS4R (18).

La precisión de los resultados numéricos obtenidos es elevada, como se muestra en la Figura 1:

\section{NUMERICAL MODEL}

\subsection{Validation of the model}

The material model used for concrete is a smeared crack model (15), with a tension softening behavior in the direction normal to the crack surface. The tangential behavior is based on the shear retention model in which the postcracked shear stiffness decreases as the crack opening increases. The mathematical form used for this model is the power law proposed by Rots and Blaauwerdraad (16).

In this model it is possible to define a displacement failure criterion. When the local displacement reaches this value, the element fails and is removed from the mesh. This failure value has been set to the crack opening at which the stresses in the element have already reached a zero value. This brittle failure criterion allows to visualize the crack paths.

To validate the used material model, it has been developed a numerical model of a notched beam subjected to threepoint bend test, and the results have been compared with experimental data (17). The model has been performed in Abaqus/Explicit. The elements are CPS4R (18).

The numerical results are in close agreement with the experimental data (Figure 1):

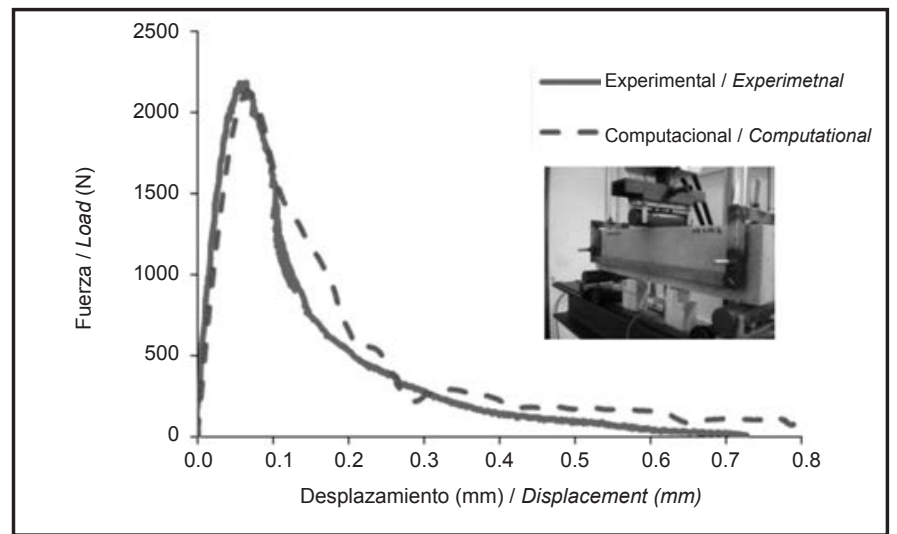

Figura 1. Comparación de los resultados experimentales y numéricos de la curva P-ס para el ensayo a flexión en tres puntos sobre una probeta entallada.

Figure 1. Comparison of experimental $P-\delta$ curve and numerical results of the three-point-bending test on single edge notched beams.

\subsection{Aplicación al estudio de la junta}

Se realiza un modelo de la junta, con una llave y con tres llaves. El modelo realizado reproduce el ensayo de junta a cortante realizado experimentalmente por Zhou (3). El

\subsection{Application of the model to the study of the joint}

It has been developed a model of a joint with one and three keys to reproduce the shear joint test carried out by Zhou (3). The model consists of two independent parts 
modelo consta de dos partes independientes en contacto, que se muestran en la Figura 2. La fuerza de pretensado exterior se modeliza mediante dos cargas externas que comprimen la junta. Las condiciones de contorno aplicadas impiden el desplazamiento vertical en la superficie inferior y el desplazamiento horizontal en su punto medio. in contact as shown in Figure 2. The prestressing force is modeled as two external loads that compress the joint. The applied boundary conditions do not allow the vertical displacement of the bottom surface or the horizontal displacement of its central point.

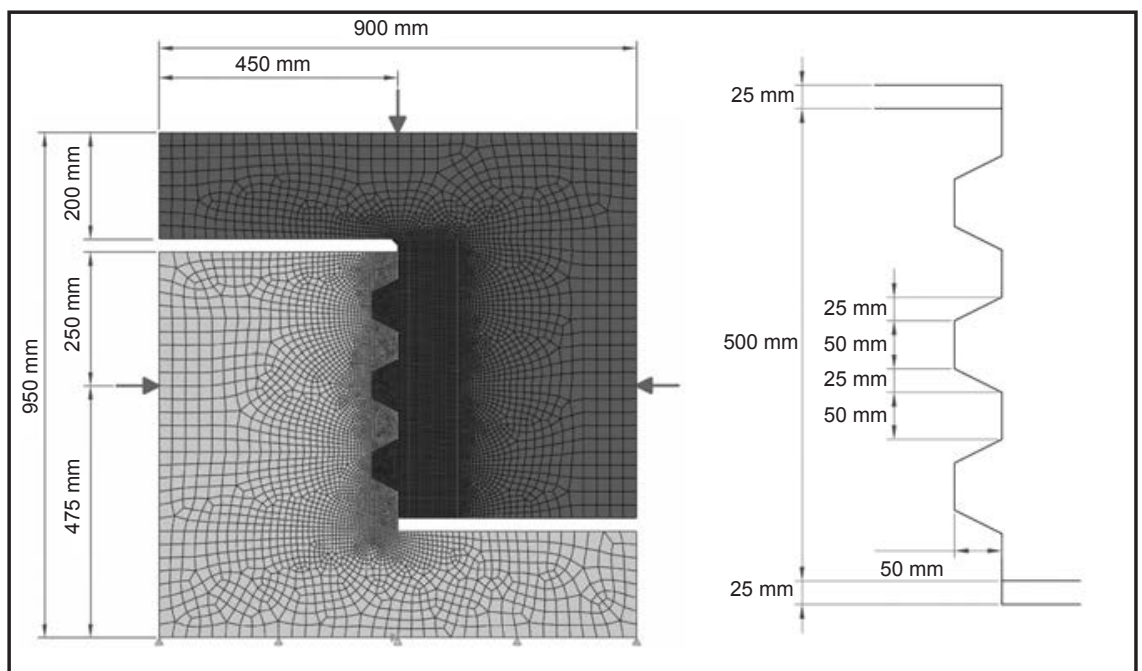

Figura 2. Modelo de elementos finitos del ensayo a cortante de junta con tres llaves y detalle de la geometría de las llaves. Figure 2. Finite element model of shear test on three-keyed joint and detail of the geometry of the keys.

La simulación se ha realizado mediante control en desplazamiento. La carga vertical aplicada en la parte superior central se modela como un desplazamiento impuesto que crece desde cero hasta el desplazamiento que provoca la rotura total de la junta.

Para modelizar el contacto en la dirección normal a las superficies se utiliza el modelo Hard contact (18) que implica que las superficies pueden separarse y entrar en contacto de nuevo, que dichas superficies no transmiten tracciones, y que no es posible que una superficie penetre a la otra. El comportamiento en la dirección tangencial se basa en el modelo de fricción de Coulomb, siendo el coeficiente de rozamiento hormigón-hormigón utilizado el obtenido experimentalmente por Zhou (3), cuyo valor es $\mu=0,72$.

Las propiedades del material consideradas en el modelo son: resistencia a compresión $50 \mathrm{MPa}$, resistencia a tracción directa 4,5 $\mathrm{MPa}$, módulo de deformación longitudinal $34,4 \mathrm{GPa}$ y energía de fractura $56 \mathrm{~N} / \mathrm{m}$. La ley de comportamiento utilizada para definir el comportamiento del hormigón en compresión se basa en el diagrama de Sargin modificado, propuesto en el Eurocódigo 2. Para definir el comportamiento en tracción consideramos una rama de ablandamiento lineal.

En las Tablas 1 y 2 se muestra la comparación de la resistencia de la junta obtenida con el modelo y experimentalmente.
The vertical load has been applied in the central point of the top surface, modeled as an imposed displacement rising from zero to the displacement that causes the failure of the joint.

To model the contact in the surface normal direction, the Hard contact model has been used (18). In this model, the surfaces are able to separate and to come in contact again. The model does not allow the penetration of one surface into the other one and there is no transfer of tensile stress across the interface. The tangential behavior is based on the Coulomb friction model with a friction coefficient between concrete surfaces of $\mu=0.72$. This value was obtained experimentally by Zhou (3).

The material properties considered in the model are: compressive strength $50 \mathrm{MPa}$, direct tensile strength 4.5 $\mathrm{MPa}$, modulus of elasticity $34.4 \mathrm{GPa}$ and fracture energy $56 \mathrm{~N} / \mathrm{m}$. The stress-strain relationship for concrete in compression is based on the Sargin's curve, which has been used in Eurocode 2. To define the tensile behavior, a linear softening branch has been used.

Tables 1 and 2 show the comparison of the joint capacity numerically and experimentally obtained. 
Tabla 1 / Table 1

Comparación de la resistencia a cortante de la junta con una llave obtenida numérica y experimentalmente. Comparison of numerical and experimental results of shear capacity of single-keyed joint.

\begin{tabular}{|c|c|c|c|c|c|c|c|c|c|}
\hline & \multicolumn{3}{|c|}{$\begin{array}{c}\text { Modelo numérico / } \\
\text { Numerical model }\end{array}$} & \multicolumn{3}{c|}{$\begin{array}{c}\text { Ensayo experimental / } \\
\text { Experimental test }\end{array}$} & \multicolumn{4}{c|}{ Error (\%) } \\
\hline$\sigma_{n}(\mathrm{MPa})$ & 1 & 2 & 3 & 1 & 2 & 3 & 1 & 2 & 3 \\
\hline $\mathrm{V}_{n}(\mathrm{kN})$ & 221 & 333 & 373 & 211 & 335 & 360 & 4.7 & 0.6 & 3.6 \\
\hline
\end{tabular}

Tabla 2 / Table 2

Comparación de la resistencia a cortante de la junta con tres llaves obtenida numérica y experimentalmente. Comparison of numerical and experimental results of shear capacity of three-keyed joint.

\begin{tabular}{|c|c|c|c|c|c|c|c|c|c|c|c|c|}
\hline \multirow[b]{2}{*}{$\sigma_{n}(\mathrm{MPa})$} & \multicolumn{4}{|c|}{$\begin{array}{c}\text { Modelo numérico I } \\
\text { Numerical model }\end{array}$} & \multicolumn{4}{|c|}{$\begin{array}{l}\text { Ensayo experimental / } \\
\text { Experimental test }\end{array}$} & \multicolumn{4}{|c|}{ Error (\%) } \\
\hline & 0.5 & 1 & 1.5 & 2 & 0.5 & 1 & 1.5 & 2 & 0.5 & 1 & 1.5 & 2 \\
\hline $\mathrm{V}_{n}(\mathrm{kN})$ & 425 & 573 & 691 & 793 & 392 & 471 & 661 & 740 & 8.4 & 21.7 & 4.5 & 7.2 \\
\hline
\end{tabular}

El error obtenido en la comparación es en la mayoría de los casos menor al 9\%. Sólo para el caso de junta con tres llaves y 1 MPa de presión de pretensado el error es del $21,7 \%$. Hay que tener en cuenta que la resistencia característica a compresión del hormigón obtenida experimentalmente de los casos mostrados es de 53,4 MPa con un coeficiente de variación del $21 \%$, que afecta significativamente a la resistencia a cortante.

La evolución de las fisuras y los patrones de grietas obtenidos mediante análisis numérico (Figura 3) son muy similares a los experimentales (3) observándose la rotura sucesiva de las llaves.
In most cases, the error obtained is less than 9\%. Only in the case of three-keyed joint and a prestressing stress of $1 \mathrm{MPa}$, the error is $21.7 \%$. It should be noted that the characteristic concrete compressive strength experimentally obtained for the cases shown in Tables 1 and 2 is $53.4 \mathrm{MPa}$ and has a variation coefficient of $21 \%$. This significantly affects to the shear capacity.

The crack path evolution and the final pattern numerically obtained (Figure 3) are very similar to the experimental ones (3) and the sequential failure of the keys can be seen.

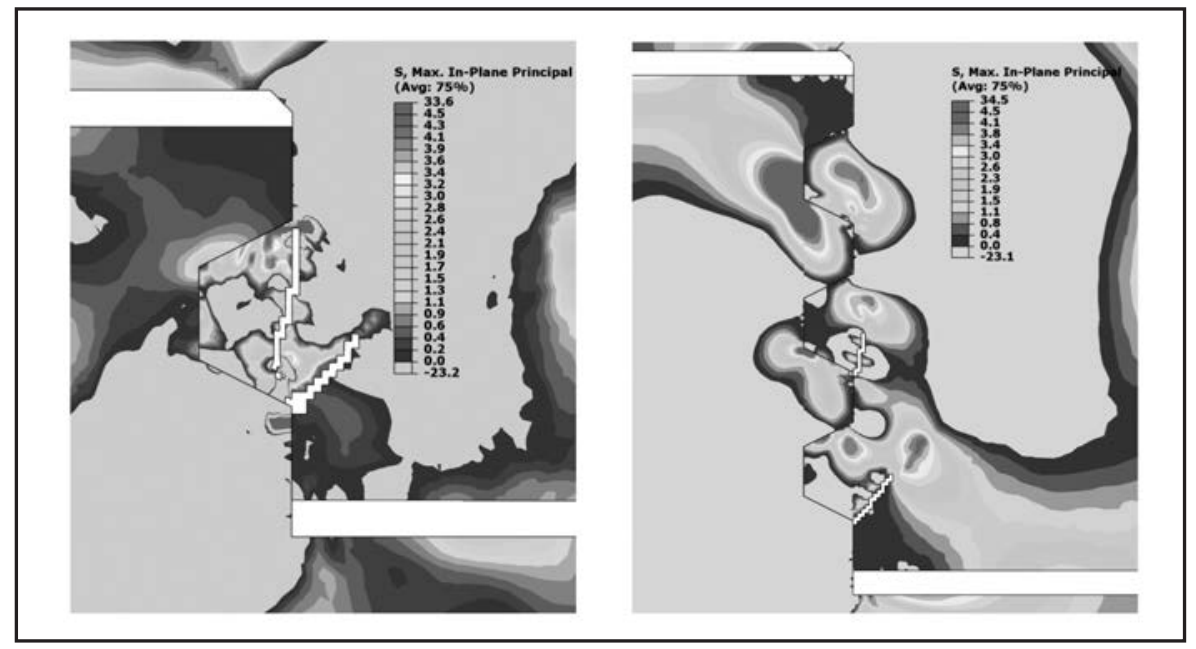

Figura 3. Patrones de grietas obtenidos mediante análisis numérico para el caso de 1 y 3 llaves. Figure 3. Crack patterns obtained from numerical analysis for 1 and 3 keys.

Una vez validado el modelo se aplica al caso de junta con cinco y siete llaves (Figura 4), para 1, 2 y 3 MPa de presión de pretensado.
After the model has been validated, it is applied to the joint with five and seven keys (Figure 4), with a prestressing stress of 1,2 and $3 \mathrm{MPa}$. 


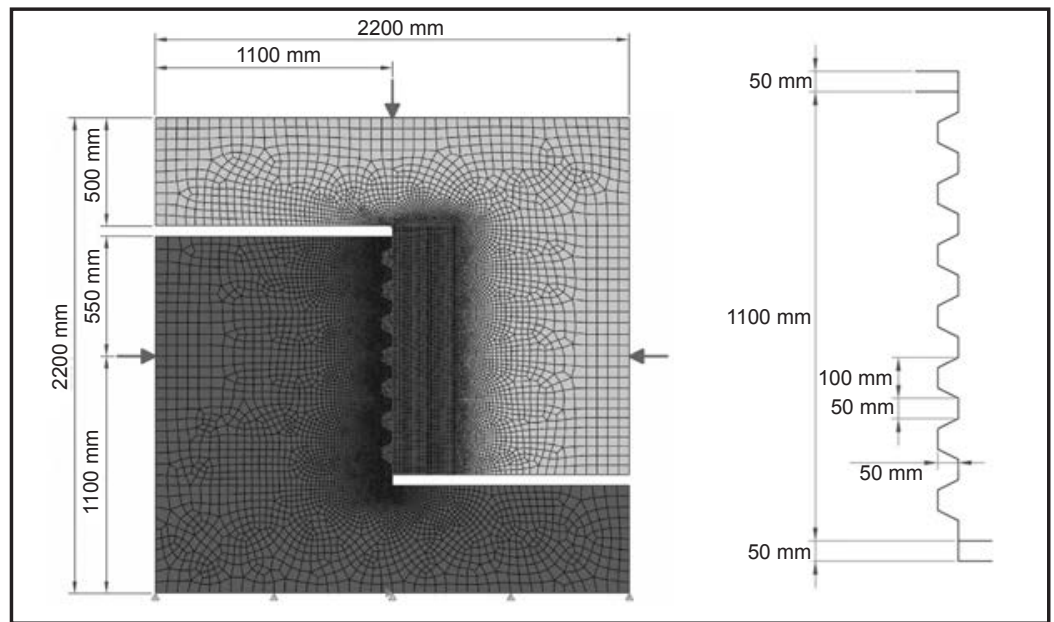

Figura 4. Modelo de elementos finitos del ensayo a cortante de junta con siete llaves y detalle de la geometría de las llaves. Figure 4. Finite element model of shear test on seven-keyed joint and detail of the geometry of the keys.

\section{RESULTADOS}

Con los resultados numéricos obtenidos de la resistencia a cortante para distintos valores de la tensión de compresión en la junta y del número de llaves (Tabla 3), se realiza un ajuste de mínimos cuadrados. Así, se obtiene la siguiente fórmula [5] para la estimación de la resistencia a cortante para el caso de hormigón de 50 MPa de resistencia a compresión y presión de pretensado inferior a $3 \mathrm{MPa}$ :

\section{RESULTS}

With the obtained numerical results of the shear capacity for different values of the prestressing stress and the number of keys (Table 3), a regression adjustment has been made, thereby obtaining a formula to estimate the shear capacity of dry keyed joints [5]. This formula is only valid for concrete compressive strength of $50 \mathrm{MPa}$ and a prestressing stress up to $3 \mathrm{MPa}$ :

$$
V_{n}=7.118 A_{k}\left(1-0.064 N_{k}\right)+2.436 A_{s m} \sigma_{n}\left(1+0.127 N_{k}\right)
$$

Siendo:

$N_{k}=$ El número de llaves en la junta.

Comparando los valores numéricos con los procedentes de la fórmula [5], se aprecia cómo la fórmula se ajusta a los resultados obtenidos con un error máximo de 8,7\%, siendo válida para describir el comportamiento de la junta en función del número de llaves y de la presión de pretensado (Tabla 3).
Where:

$N_{k}=$ Number of keys in the joint.

Comparing the numerical values with those obtained from the formula [5] it can be seen that the formula reproduces the numerical results with a maximum error of $8.7 \%$. The formula describes the joint behavior depending on the number of keys and the prestressing stress (Table 3).

Tabla 3 / Table 3

Resistencia cortante $(\mathrm{kN})$ frente a presión de pretensado (MPa) para distinto número de llaves. Shear capacity $(K N)$ versus prestressing stress (MPa) for different number of keys.

\begin{tabular}{|c|c|c|c|c|c|c|c|c|c|}
\hline & \multicolumn{3}{|c|}{$\begin{array}{l}\text { Modelo numérico I } \\
\text { Numerical model }\end{array}$} & \multicolumn{3}{|c|}{$\begin{array}{l}\text { Fórmula de ajuste I } \\
\text { Regression equation }\end{array}$} & \multicolumn{3}{|c|}{ Error (\%) } \\
\hline & $1 \mathrm{MPa}$ & $2 \mathrm{MPa}$ & $3 \mathrm{MPa}$ & $1 \mathrm{MPa}$ & $2 \mathrm{MPa}$ & $3 \mathrm{MPa}$ & $1 \mathrm{MPa}$ & $2 \mathrm{MPa}$ & $3 \mathrm{MPa}$ \\
\hline 1 llave / key & 221 & 333 & 373 & 235 & 304 & 372 & 6.3 & 8.7 & 0.3 \\
\hline 3 llaves / keys & 573 & 793 & 914 & 600 & 768 & 936 & 4.7 & 3.2 & 2.4 \\
\hline 5 llaves / keys & 918 & 1209 & 1484 & 904 & 1202 & 1501 & 1.5 & 0.6 & 1.1 \\
\hline 7 llaves / keys & 1153 & 1588 & 2098 & 1148 & 1608 & 2068 & 0.4 & 1.3 & 1.4 \\
\hline
\end{tabular}




\section{DISCUSIÓN DE RESULTADOS}

Para poder comparar los resultados dados por la fórmula de ATEP [1] en valores últimos con los valores nominales de la AASTHO [2], dividimos los valores dados por la fórmula de la ATEP por el factor de reducción de resistencia de la AASTHO, cuyo valor es 0,75. En las Figuras 5, 6, 7 y 8 se compara la resistencia a cortante obtenida mediante la fórmula de estimación de la resistencia a cortante obtenida en este trabajo [5] con las fórmulas propuestas por la ATEP [1], por la AASHTO [2], por Turmo [3] y por Rombach [4], para el caso de 1, 3, 5 y 7 llaves en función de la presión de pretensado.

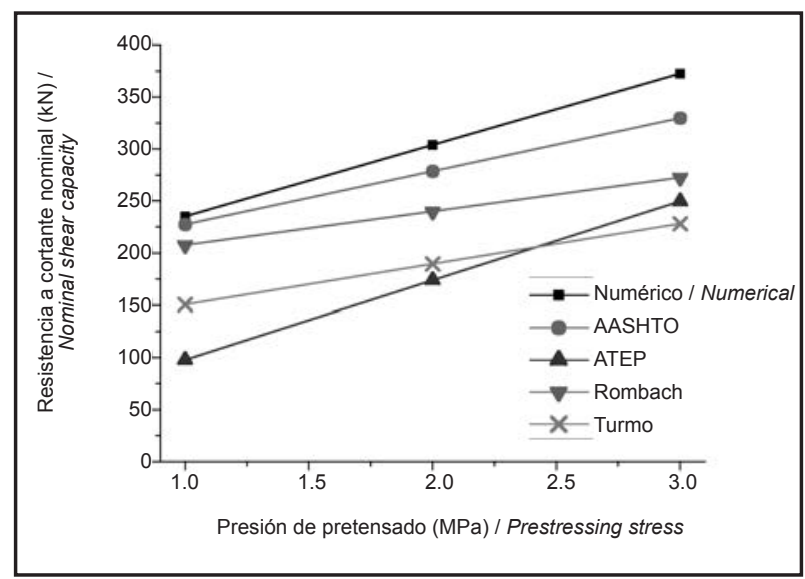

Figura 5. Resistencia a cortante frente a presión de pretensado para junta con una llave.

Figure 5. Nominal shear capacity versus prestressing stress for single-keyed joint.

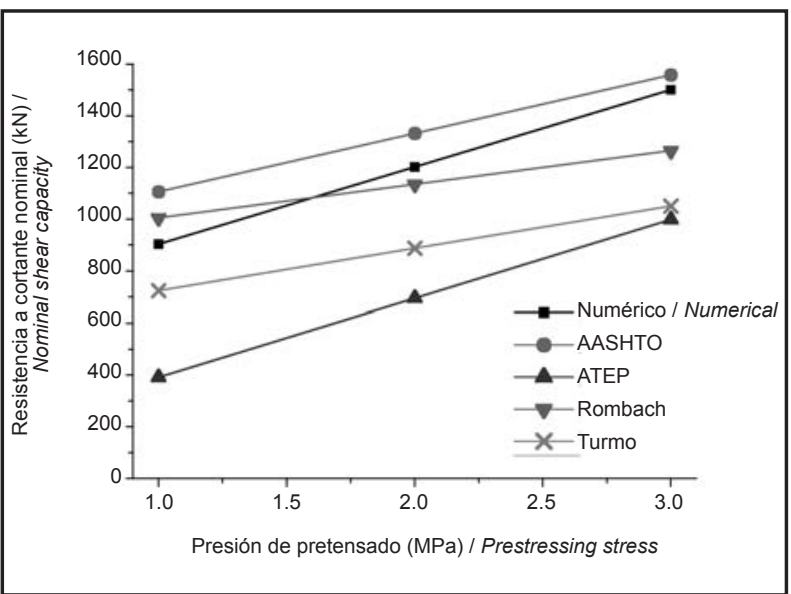

Figura 7. Resistencia a cortante frente a presión de pretensado para junta con cinco llaves.

Figure 7. Nominal shear capacity versus prestressing stress for five-keyed joint.

Los resultados según la fórmula de la AASTHO [2] quedan del lado de la inseguridad para más de una llave, como ya demostró experimentalmente Zhou (3). Sin embargo,

\section{DISCUSSION OF RESULTS}

To compare the estimations given by the ATEP formula [1], which are ultimate values, with the nominal values from the AASHTO formula [2], the ATEP estimations must be divided by the strength reduction factor from the AASHTO, whose value is 0.75 . Figures 5, 6, 7 and 8 show the comparison of the shear capacity obtained from the estimation formula presented in this paper [5] with the formulas proposed by ATEP [1], AASHTO [2], Turmo [3] and Rombach [4], for 1, 3, 5 and 7 keys and depending on the prestressing stress.

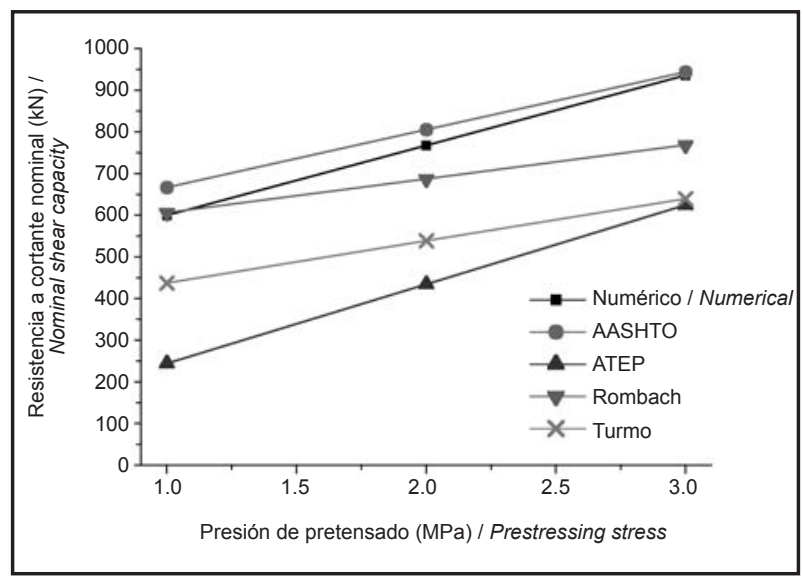

Figura 6. Resistencia a cortante frente a presión de pretensado para junta con tres llaves.

Figure 6. Nominal shear capacity versus prestressing stress for three-keyed joint.

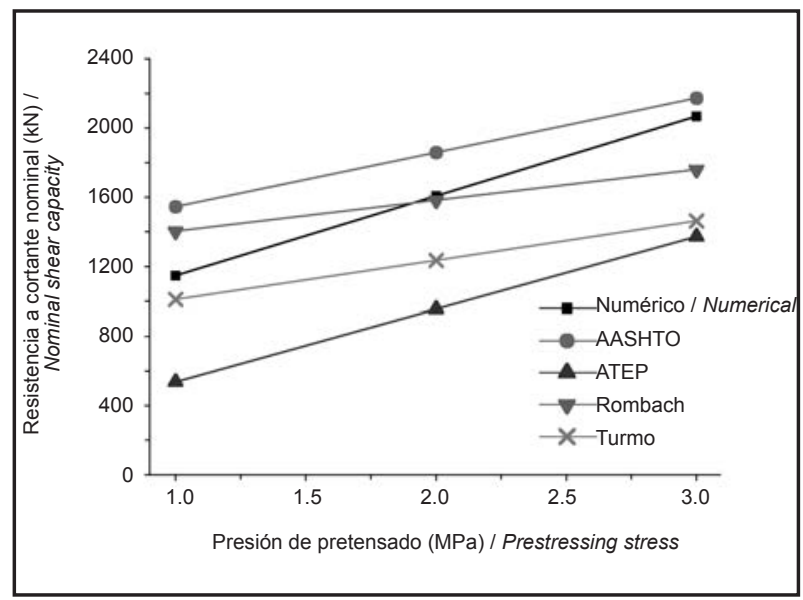

Figura 8. Resistencia a cortante frente a presión de pretensado para junta con siete llaves.

Figure 8. Nominal shear capacity versus prestressing stress for seven-keyed joint.

The results from the AASHTO formula [2] overestimate the shear capacity of multiple-keyed dry joints, as Zhou demonstrated experimentally (3). On the other hand, 
los resultados según la ATEP [1] quedan muy del lado de la seguridad (1). Los resultados según la fórmula propuesta por Rombach [4] se acercan más a los resultados numéricos, pero para 5 y 7 llaves dan valores mayores. Los resultados según la fórmula propuesta por Turmo [3] presentan valores más conservadores para un número de llaves bajo.

Los resultados muestran una dependencia del número de llaves que no se recoge en las fórmulas existentes. Por tanto, para presiones de pretensado inferiores a $3 \mathrm{MPa}$, sería necesario introducir un coeficiente que considere esta dependencia del número de llaves (3), como se ha hecho en la fórmula de ajuste de los resultados numéricos presentada [5].

La tensión tangencial media en la junta obtenida con la fórmula de estimación [5] disminuye al aumentar el número de llaves (Figura 9). Sin embargo, este efecto es menor al aumentar la compresión en la junta. Para el caso de $3 \mathrm{MPa}$, la tensión tangencial media es independiente frente al número de llaves.

Representando la tensión tangencial media para cada tipo de junta en función de la presión de pretensado actuante en la junta, se aprecia cómo todas las líneas confluyen para $3 \mathrm{MPa}$ (Figura 10). Esto es debido a que una presión de pretensado alta en la junta hace que ésta tenga un comportamiento más plástico, permitiendo que todas las llaves puedan desarrollar su resistencia (19). Esto se observa también en el modelo numérico viendo cómo todas las llaves se fracturan casi al mismo tiempo, y no sucesivamente.

Se puede concluir por tanto que para tensiones superiores a $3 \mathrm{MPa}$ el comportamiento sería similar al de $3 \mathrm{MPa}$, siendo la tensión tangencial media en la junta independiente del número de llaves.

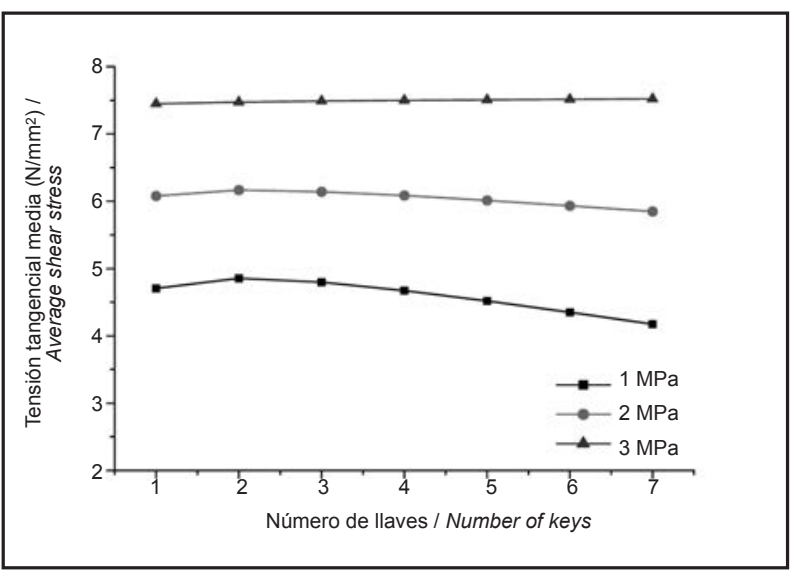

Figura 9. Tensión tangencial media en la junta frente al número de llaves para 1, 2 y $3 \mathrm{MPa}$ de presión de pretensado. Figure 9. Average shear stress transferred across the joint versus number of keys for 1, 2 and $3 \mathrm{MPa}$ of prestressing stress. the estimations from the ATEP formula [1] remain far on the conservative side (1). The values from the formula proposed by Rombach [4] are closer to the numerical results, but for 5 and 7 keys there are some values bigger than the numerical ones. The formula proposed by Turmo [3] gives values that are more conservative for a small number of keys.

The results show a dependence on the number of keys that has not been expressed by any existing formula. Therefore, for prestressing stress less than $3 \mathrm{MPa}$, it would be necessary to introduce a coefficient to consider this dependence (3), like the regression equation presented in this paper [5].

The average shear stress transferred across the joint obtained from the estimation formula [5] decreases as the number of keys increases (Figure 9). However, this effect declines gradually as the compressive stress in the joint increases. In the case of $3 \mathrm{MPa}$, the average shear stress becomes independent of the number of keys.

Representing graphically the average shear stress for each type of joint depending on the prestressing stress applied to the joint, it can be seen that all the lines converge for $3 \mathrm{MPa}$ (Figure 10). This is due to the fact that a high compressive stress makes the joint have a more plastic behavior (19), so all the keys are able to fully develop their capacity. This can also be seen in the numerical model where the keys fail almost at the same time and not sequentially.

Therefore, it can be concluded that for compressive stress greater than $3 \mathrm{MPa}$ the behavior would be similar to the case of $3 \mathrm{MPa}$, where the average shear stress transferred across the joint is independent of the number of keys.

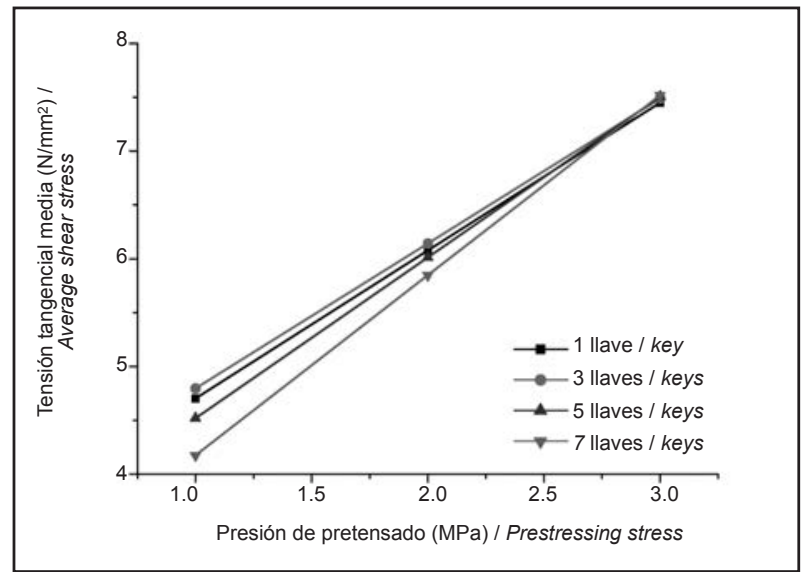

Figura 10. Tensión tangencial media en la junta frente a la presión de pretensado, para 1, 3, 5 y 7 llaves.

Figure 10. Average shear stress transferred across the joint versus prestressing stress for 1, 3, 5 and 7 keys. 


\section{CONCLUSIONES}

La tensión tangencial media en las juntas secas con llaves disminuye al aumentar el número de llaves, debido a que se produce una rotura sucesiva de las llaves. Sin embargo, las fórmulas actuales no incluyen ningún factor que describa esta dependencia, lo que hace que por ejemplo la formulación de la AASTHO pudiera infravalorar la resistencia para el caso de llaves múltiples.

Se ha realizado un modelo numérico de junta con 1, 3, 5 y 7 llaves y se ha obtenido una fórmula de ajuste de los resultados obtenidos que permite la estimación de la resistencia a cortante en función del número de llaves y de la presión de pretensado (hasta $3 \mathrm{MPa}$ ) para una resistencia característica a compresión del hormigón de $50 \mathrm{MPa}$. En la bibliografía se señala la importancia de la dependencia del número de llaves pero no se considera en ninguna formulación.

La tensión tangencial media en la junta disminuye al aumentar el número de llaves, pero este efecto es menor para mayor presión de pretensado en la junta, siendo inapreciable para $3 \mathrm{MPa}$. Se concluye que para valores mayores de la presión de pretensado el comportamiento es independiente del número de llaves. Por tanto, si la formulación actual para el cálculo de la resistencia a cortante de juntas secas con llaves se aplica para presiones de pretensado mayores de $3 \mathrm{MPa}$, no sería necesario que recogieran la dependencia del número de llaves.

\section{AGRADECIMIENTOS}

Los autores desean agradecer al Ministerio de Educación y Ciencia la financiación para la realización del presente trabajo, a través del proyecto BIA2010-21399-C02-02.

\section{CONCLUSIONS}

The average shear stress transferred across the dry keyed joints decreases as the number of keys increases, due to the fact that the keys fail sequentially. However, the existing formulas do not include any factor that takes into account this dependence. Because of this, the AASHTO formula may underestimate the shear capacity of the joints in the case of multiple keys.

It has been developed a numerical model of a joint with 1, 3, 5 and 7 keys, and a regression equation of the obtained results has been presented. This equation estimates the shear capacity depending on the number of keys and the prestressing stress (until $3 \mathrm{MPa}$ ) for a characteristic concrete compressive strength of $50 \mathrm{MPa}$. In the literature, it has been pointed out the relevance of the dependence on the number of keys, but it has not been included in any formula.

The average shear stress transferred across the joint decreases as the number of keys increases, but this effect declines with higher prestressing stress in the joint, becoming negligible for $3 \mathrm{MPa}$. It can be concluded that for higher prestressing stress the behavior is independent of the number of keys. Consequently, if the existing formulation to estimate the shear capacity of dry keyed joints is applied for prestressing stress superior to $3 \mathrm{MPa}$, it would not be necessary to include any factor taking into account the dependence on the number of keys.

\section{ACKNOWLEDGEMENTS}

The authors would like to acknowledge the financial support provided for this research by the Spanish Ministry of Science and Technology under the project BIA201021399-C02-02.

\section{BIBLIOGRAFÍA / BIBLIOGRAPHY}

(1) Turmo, J.; Ramos, G.; Aparicio, A. C.: "Resistencia de juntas secas conjugadas de puentes de dovelas prefabricadas de hormigón: propuesta para el Eurocódigo 2", Mater. Construcc. vol. 56, no 282, pp. 45-52 (2006). doi:10.3989/mc.2006.v56.i282.26.

(2) Buyukozturk, O.; Bakhoum, M. M.; Beattie, S. M.: "Shear behavior of joints in precast concrete segmental bridges", Journal of structural engineering New York, N.Y., vol. 116, no 12, pp. 3380-3401 (1989). doi:10.1061/(ASCE)0733-9445(1990)116:12(3380).

(3) Zhou, X.; Mickleborough, N.; Li, Z.: "Shear strength of joints in precast concrete segmental bridges", ACI Structural Journal, vol. 102, no 1, pp. 3-11 (2005).

(4) Wakasa, T.; Otsuka, H.; Yabuki, W.: "Experimental study of the shear strength of precast segmental beams with external prestressing", Structural Concrete, vol. 6, no 2, pp. 63-80 (2005).

(5) Turmo, J.; Ramos, G.; Aparicio, A. C.: "Shear strength of dry joints of concrete panels with and without steel fibres. Application to precast segmental bridges", Engineering Structures, vol. 28, no 1, pp. 23-33 (2006). doi:10.1016/j.engstruct.2005.07.001.

(6) Issa, M. A.; Abdalla, H. A.: "Structural behavior of single key joints in precast concrete segmental bridges", Journal of Bridge Engineering, vol. 12, no 3, pp. 315-324 (2007). doi:10.1061/(ASCE)1084-0702(2007)12:3(315). 
(7) Kaneko, Y.; Connor, J. J.; Triantafillou, T. C.; Leung, C. K.: "Fracture mechanics approach for failure of concrete shear key. I: theory", Journal of Engineering Mechanics, vol. 119, no 4, pp. 681-700 (1993). doi:10.1061/(ASCE)0733-9399(1993)119:4(681).

(8) Kaneko, Y.; Connor, J. J.; Triantafillou, T. C.; Leung, C. K.: "Fracture mechanics approach for failure of concrete shear key. II: verification", Journal of Engineering Mechanics, vol. 119, no 4, pp. $701-719$ (1993). doi:10.1061/(ASCE)0733-9399(1993)119:4(701).

(9) Rombach, G.; Specker, A.: "Finite Element Analysis of Externally Prestressed Segmental Bridges", in Proceedings of the Fourteenth Engineering Mechanics Conference (EM 2000), Austin (2000).

(10) Turmo, J.; Ramos, G.; Aparicio, A. C.: "FEM modelling of unbonded post-tensioned segmental beams with dry joints", Engineering Structures, vol. 28, no 13, pp. 1852-1863 (2006). doi:10.1016/j.engstruct.2006.03.028.

(11) Veletzos, M. J.; Restrepo, J. I.: "Modeling of jointed connections in segmental bridges", Journal of Bridge Engineering, vol. 16, no 1, pp. 139-147 (2011). doi:10.1061/(ASCE)BE.1943-5592.0000112.

(12) ATEP: Proyecto y construcción de puentes y estructuras con pretensado exterior. H.P.10-96 vol. E-6. Madrid, Colegio de Ingenieros de Caminos, Canales y Puertos (1996).

(13) AASHTO: Guide Specifications for Design and Construction of Segmental Concrete Bridges, second ed., American Association of State Highway and Transportation Officials (1999).

(14) Rombach, G.: "Dry joint behavior of hollow box girder segmental bridges", in FIP Symposium "Segmental Construction in Concrete", New Delhi (2004).

(15) Bažant, Z. P.; Oh, B. H.: "Crack band theory for fracture of concrete", Materials and Structures, vol. 16, no 3, pp. 155-177 (1983). doi:10.1007/bf02486267.

(16) Rots, J. G.; Blaauwendraad, J.: "Crack models for concrete: discrete or smeared? Fixed multi-directional or rotating?", Heron, vol. 34, no 1, pp. 3-59 (1989).

(17) Cifuentes, H.: "Análisis del comportamiento en fractura y del efecto de borde en hormigones de altas prestaciones reforzados con fibras de polipropileno", PhD Thesis, Universidad de Sevilla, Escuela Superior de Ingenieros, Sevilla (2010).

(18) Abaqus Analysis User's Manual, Versión 6.9 ed., Abaqus, Dassault Systèmes Simulia Corp. (2009).

(19) Rombach, G.; Specker, A.; Zhou, X.; Mickleborough, N.; Li, Z.; Turmo, J.; Ramos, G.; Aparicio, Á. C.: "Discussion on 'Shear strength of joints in precast concrete segmental bridges"', ACI Structural Journal, vol. 102, no 6, pp. 901-904 (2005). 